\title{
Effect of Different Irrigation Systems, Pulse Irrigation Technique and Silicon Application on Maize Growth, Yield and Water Relations under Toshka Climatic Conditions
}

\author{
Abaza, A.S.D. ${ }^{1}$; H.M.A. Ragheb ${ }^{2}$; M. K. Rushdi ${ }^{2}$ and O.H.A. Wahpalla ${ }^{1}$ \\ ${ }^{1}$ Water Studies and Research Complex (WSRC), Station, National Water Research \\ Center, Toshka - Abu Simbel City, Egypt. \\ ${ }^{2}$ Soil and water Dept., Faculty of Agriculture, Assiut University, Assiut, Egypt. \\ Received on: 15/11/2016 \\ Accepted for publication on: 18/12/2016
}

\begin{abstract}
Field experiments were carried out at the experimental farm of Water Studies and Research Complex (WSRC) Station, National Water Research Center, Toshka - Abu Simbel city, Egypt during the two summer seasons of 2015 and 2016 to study the effect of three irrigation methods including new types of micro irrigation, pulse irrigation technique and silicon application on water relations of maize (Giza - 358, variety) as well as yield and yield components. The experiments were laid out in split plots design with three replicates and consisted of three treatments.

The results indicated that the effect of pulse irrigation technique on water use efficiency were larger than the effect of irrigation system and silicon application, the mean values of water use efficiency were $\left(0.56,0.52\right.$ and $\left.0.52 \mathrm{~kg} / \mathrm{m}^{3}\right)$ for pulse irrigation technique, irrigation system and silicon application, respectively. Also the results showed that grains yield (ton/fed) was increased for combined irrigation system and pulse irrigation technique which had been recorded (1.4 ton/fed) while the mean values of silicon application were ( 1.3 ton/fed).

Finally, under the current experimental conditions, it could be concluded that pulse technique and silicon application under combination irrigation system is suitable under Toshka climatic conditions and caused significant increases in WUE and grain yield.
\end{abstract}

Keywords: Maize, Silicon application, Pulse irrigation technique.

\section{Introduction}

Agriculture consumes the largest amount of the available water in Egypt, with its share exceeding $85 \%$ of the total demand for water. On the other hand, several studies showed that the Nile River is very sensitive to temperature and precipitation changes mainly because of its low run off ratio (4\%). Egypt is affected by climate change impacts (MWRI, 2014).

Water is fast becoming an economically scarce resource in many areas of the world especially in arid and semiarid regions. In Egypt, limited water resources coupled with high population induce a great competition for water supply that makes conservation and efficient use of water obligatory. Moreover, the newly reclaimed soils such as in Toshka district are facing numerous problems, amongst the water scheduling of limited amounts of water for high yields of some selected low water consuming and high valuable crops is urgently needed (El-Shamly, 2014). 
Field evaluation of irrigation system performance is essential to improve irrigation management. Volumetric water control and distribution uniformity in irrigation system are essential factors in achieving accurate water applications, (Smith and Watts, 1986). Surface irrigation is the most widely used irrigation method; this is due to its low capital and maintenance costs, and low energy requirements (Walker, 1989).

Subsurface drip irrigation (SDI) is the most advanced method of irrigation, which enables the application of the small amounts of water to the soil through the drippers placed below the soil surface with discharge rates generally in the similar range as surface drip irrigation. The performance of drip irrigation system should be quantified in relation to its design, management, operation and efficient use of water. Quantification allows the users to determine and control the discharge, amount and timings of water application, so that the crop water requirements are most important in a planned and effective manner (Ayars et al., 1999).

The earth crust by weight is constituted about $25.7 \%$ silicon; hence it is the $2^{\text {nd }}$ most plenteous element after oxygen (Epstein, 2009). Earlier it has been reported that under water deficit condition grasses supplied with silicon-applied plants of grasses had higher leaf water potential than those plants grown without silicon fertilization (Agarie et al., 1998). Liang et al., 1999 reported that silica-cuticle double layer formed on leaf epidermis is liable for this improved water potential. Hence, suggesting an induction of drought tolerance by $(\mathrm{Si})$ due to reducing transpiration loss of water under moisture stress condition. Optimization of $(\mathrm{Si})$ nutrition results in increased weight and volume of roots by 20 to $200 \%$, and enhanced drought and salt resistance of cultivated plants. Active (Si) compounds are shown to be extremely important for formation of soil fertility. They have a direct effect on soil texture and increase water-holding capacity by 20 to $30 \%$ and exchange capacity by 10 to $25 \%$ (Matichenkov and Bocharnikova 2001). Also, Gong et al., 2005 stated that adding Si could improved the water status of waterstressed maize plants.

Overall Silicon nutrition has several beneficial effects on plant growth largely due to its unique physiological role (Kojic et al., 2012). Its application improved the leaf chlorophyll contents, leaf water potential, water relations and gas exchange (Mali and Aery, 2008 and Pei et al., 2010).

Where drip irrigation is used, you may need to irrigate more than once a day to meet peak water requirements. If the drip system drains out after each irrigation, break the irrigation down into the longest pulses possible to reduce losses to drainage. High irrigation frequency might provide desirable conditions for water movement in soil and for water uptake by roots. (Segal et al., 2000).

Maize (Zea mays L.) is considered one of the most important cereal crops in Egypt. Total annual area cultivated with maize varieties was estimated by 1.5-2.0 million feddan. Total national production of maize is 
about 5.43 million tons, while the demand is for at least 7.0 million tons. This reflects the size of the problem and efforts that needed to increase maize production. This can be achieved by breeding high yielding varieties and by the application of improved agro-techniques (ElAtawy et al., 2010). The actual water use by crop varies greatly due to the variation of seasons and locations, depending on the evaporative conditions of the atmosphere and the crop characteristics (Nabila et al., 2014). Therefore, the knowledge of the optimum amounts of water required for obtaining maximum yield and high quality is essential. It has been reported that soil moisture limits the growth of the plants before it reaches the permanent wilting point. Water stress affects nearly every process in the plant, where it reduces cell turgor. The size of assimilation leaf area and number of potential storage sites for produced dry matter (Simpson, 1981). It is well established that water supply affects the growth and production of grown crops, limited soil moisture critically influenced the performance of maize plants by reducing plant height, weight and size of assimilating leaf area and dry matter accumulation (Mahrous, 1991 and Hefni et al., 1993). Yield and yield components of maize plants were also affected by limited water supply Ibrahim et al., (1992) and ElSheikh (1994) reported that the plants exposed to water stress or skipping one irrigation during pre or post silking reduced the grain yield by 9 and $10 \%$ compared to the conventional irrigation, respectively.

The objective of this research was to study the effects of different irrigation systems, pulse irrigation technique and silicon application on the growth, yield, yield components and water relations of Zea mays under Toshka climatic conditions.

\section{Materials and Methods}

Field experiments were carriedout at the experimental farm of Water Studies and Research Complex (WSRC), station, National Water Research Center, Toshka - Abu simbel city, Egypt during the two summer seasons of soil 2015 and 2016. The soil texture is sand. Some physical and chemical properties and irrigation water were measured according to Klute (1986) and Page (1982) and were given in Table 1. 
Table 1. Some physical and chemical properties of the studied soil and ground water of experimental site before cultivation.

A- Some physical properties of the studied soil of the experimental site before cultivation.

\begin{tabular}{|l|c|c|c|c|c|c|c|c|c|}
\hline \multirow{2}{*}{$\begin{array}{c}\text { Soil depth } \\
(\mathbf{c m})\end{array}$} & \multicolumn{3}{|c|}{$\begin{array}{c}\text { Particle size } \\
\text { distribution }(\%)\end{array}$} & $\begin{array}{l}\text { Tex. } \\
\text { class }\end{array}$ & $\begin{array}{c}\text { S.P. } \\
(\%)\end{array}$ & $\begin{array}{c}\text { F.C } \\
(\%)\end{array}$ & W.P (\%) & $\begin{array}{c}\text { A.W. } \\
(\mathbf{\%})\end{array}$ & $\begin{array}{c}\text { BD } \\
\left(\mathbf{g} / \mathbf{c m}^{3}\right)\end{array}$ \\
\cline { 2 - 9 } & Sand & Silt & Clay & & & & & & \\
\hline $\mathbf{0 - 2 0}$ & 94.16 & 0.69 & 5.15 & S & 23.80 & 12.5 & 2.0 & 10.5 & 1.60 \\
\hline $\mathbf{2 0 - 4 0}$ & 95.77 & 1.40 & 2.83 & S & 23.10 & 12.5 & 2.0 & 10.5 & 1.58 \\
\hline
\end{tabular}

$\mathrm{S}=$ Sand $\mathrm{S} . \mathrm{P}=$ Saturation percent $\quad \mathrm{F} . \mathrm{C}=$ Field capacity

$\mathrm{W} . \mathrm{P}=$ Wilting point $\mathrm{A} . \mathrm{W}=$ Available water $\mathrm{B} . \mathrm{D}=$ Bulk density

B- Some chemical properties of the studied soil of the experimental site before cultivation.

\begin{tabular}{|c|c|c|c|c|c|c|c|c|c|c|c|}
\hline \multirow{3}{*}{$\begin{array}{l}\text { Soil depth } \\
\quad(\mathrm{cm})\end{array}$} & \multirow{3}{*}{$\begin{array}{c}\mathrm{CaCO}_{3} \\
(\%)\end{array}$} & \multirow{3}{*}{$\begin{array}{l}\text { OM } \\
(\%)\end{array}$} & \multirow{3}{*}{$\mathbf{p H}^{*}$} & \multirow{3}{*}{$\begin{array}{c}E C^{* *} \\
(\mathrm{dS} / \mathrm{m}) \\
(1: 1) \\
\text { Soil } \\
\text { extract }\end{array}$} & \multicolumn{7}{|c|}{ Soluble ions (meq/l) } \\
\hline & & & & & \multicolumn{3}{|c|}{ Anions } & \multicolumn{4}{|c|}{ Cations } \\
\hline & & & & & $\mathrm{Cl}^{-}$ & $\begin{array}{l}\mathrm{CO}_{3}{ }^{-2}+ \\
\mathrm{HCO}_{3}{ }^{-}\end{array}$ & $\mathrm{SO}_{4}{ }^{-2}$ & $\mathrm{Na}^{+}$ & $\mathbf{K}^{+}$ & $\mathrm{Ca}^{+2}$ & $\mathrm{Mg}^{+2}$ \\
\hline $0-20$ & 13.5 & nil & 7.78 & 0.15 & 0.7 & 0.4 & 0.4 & 0.6 & 0.1 & 0.6 & 0.2 \\
\hline $20-40$ & 14.8 & nil & 7.79 & 0.16 & 0.7 & 0.4 & 0.5 & 0.6 & 0.1 & 0.7 & 0.2 \\
\hline
\end{tabular}

$* \mathrm{pH}$ in $1: 1$ soil to water suspension

**EC in 1:1 soil to water extract

C-Some chemical analysis of the ground water (irrigation water).

\begin{tabular}{|c|c|c|c|c|c|c|c|c|c|c|c|}
\hline \multirow[b]{2}{*}{ Date } & \multirow[b]{2}{*}{ pH } & \multicolumn{2}{|c|}{ TDS } & \multicolumn{4}{|c|}{ Cations (meq/l) } & \multicolumn{3}{|c|}{ Anions (meq/l) } & SAR \\
\hline & & $\begin{array}{c}\text { EC } \\
d S / m\end{array}$ & $\begin{array}{c}\mathrm{mg} / \mathrm{l} \\
(\mathrm{ppm})\end{array}$ & $\mathrm{Na}^{+}$ & $\mathbf{K}^{+}$ & $\mathrm{Mg}^{+2}$ & $\mathrm{Ca}^{+2}$ & $\mathrm{Cl}^{-}$ & $\begin{array}{l}\mathrm{CO}_{3}^{-2}+ \\
\mathrm{HCO}_{3}-\end{array}$ & $\mathrm{SO}_{4}{ }^{-2}$ & \multirow[t]{2}{*}{1.7} \\
\hline Oct -2016 & 6.70 & 0.75 & 480 & 2.6 & 0.1 & 1.3 & 3.4 & 2.3 & 1.8 & 3.4 & \\
\hline
\end{tabular}

TDS $=$ Total dissolved solids.

$\mathrm{SAR}=$ sodium adsorption ratio. 
The experiment was laid out in split plots design with three replicates and consisted of three treatments. The variables were three irrigation systems two of it are traditional irrigation systems which are (sub surface drip system, $\mathrm{I}_{1}$ and surface drip system, $\mathrm{I}_{2}$ ) while the third one is a new type of micro irrigation (Integral Drip Irrigation, $\mathrm{I}_{3}$ ) it is combination system between surface drip line \& subsurface drip leak line. Therefore it contains the same component which has been applied in surface \& subsurface drip irrigation (E.g. Head control unit and pipe lines network). The only difference was use of two laterals lines to irrigate each row (in the surface GR drip line parallel with leak line in the subsurface and connecting the two lines by tee polyethylene pipe and controlled of water pass in the drip lines by PE valve installed on each drip line). The main plots were bounded with buffer zone $(1.5 \mathrm{~m}$ width) to avoid the horizontal seepage. The split units also bounded with buffer zone $0.3 \mathrm{~m}$ to avoid the horizontal seepage. The plot with an area $45 \mathrm{~m}^{2}$ for sub-drip, combination and drip irrigation.

Also each of the studied sites was divided into two plots to study the effect of silicon application; the first one has non silicon applications ( $\left.\mathrm{Si}{ }_{0}\right)$ while the other one received silicon applications $\left(\mathrm{Si}_{1}\right)$ at a level of (400 mg/l sodium silicate), each division was subdivided into two areas the first one was used for pulse irrigation (P.I off), while the other one was used for continues irrigation (P.I on).
In the summer seasons of 2015 and 2016, maize grains (Giza - 358, variety) were sown in rows $800 \mathrm{~cm}$ long and $15 \mathrm{~cm}$ apart between hills on June 25 under surface drip, subsurface drip and combined irrigation systems. The lateral lines were spared at $50 \mathrm{~cm}$ apart and the drippers were at $30 \mathrm{~cm}$ apart on the lateral. Harvesting of maize plants was 100 days after planting for each season. All the agriculture practices were applied as commonly used for growing maize and carried out according to the recommendations set by the Ministry of Agriculture. Nitrogen, phosphorus and potassium fertilizers were added according to the recommended doses. Nitrogen fertilizer was applied in the form of ammonium sulphate $(20.6 \% \mathrm{~N})$ at the level of $600 \mathrm{~kg} / \mathrm{fed}$ in eight equal doses, the first one after seven days from planting and the final dose before flowering stage time. Phosphorus fertilizer in the form of calcium super phosphate $\left(15.5 \% \quad \mathrm{P}_{2} \mathrm{O}_{5}\right)$ was added at the level of $200 \mathrm{~kg} / \mathrm{fed}$ in one dose before planting. Potassium fertilizer in the form of potassium sulphate $\left(48 \% \mathrm{~K}_{2} \mathrm{O}\right)$ at the level of $50 \mathrm{~kg} /$ fed was added in the same time of adding phosphorus fertilizer.

To obtain the actual water consumptive use (C.U), the soil moisture percentage was determined gravimetrically on dry weight basis just before irrigation. Soil samples for moisture determination were taken from each $0 \mathrm{~cm}$ depth up to $30 \mathrm{~cm}$ from the soil surface by soil auger. The amount of water consumed in each irrigation interval was obtained from the difference between soil content before the follow- 
ing irrigation and field capacity. This was calculated according to Israelsen and Hansen (1962) as follows:

$$
\text { C.U. }=\mathrm{D} \times \mathrm{Pb} \times(\mathbf{Q} 2-\mathrm{Q} 1) / \mathbf{1 0 0}
$$

Where:

C.U. $=$ actual evapotranspiration.

$\mathbf{D}=$ the irrigated soil depth $(\mathrm{cm})$.

$\mathbf{P b}=$ Bulk density in $\mathrm{g} / \mathrm{cm}^{3}$.

$\mathbf{Q 2}=$ the percent of soil moisture at field capacity.

Q1= the percent of soil moisture before irrigation.

$\mathbf{E r}=$ irrigation system efficiency (\%).

The Water use efficiency (WUE) values were calculated as follows (Viets, 1965):-

WUE $=$ \{Grains yield (kg / fed.) $/$ Actual evapotranspiration $\left(\mathrm{m}^{3} /\right.$ fed.)\}

Also the irrigation water use efficiency (IWUE) is expressed as $\mathrm{kg}$ seeds $/ \mathrm{m}^{3}$ of water applied; it has been used to evaluate efficiency of the irrigation methods in producing maximum yield per water unit consumed by the crop Viets (1965) :-

IWUE $=\{$ Grains yield $(\mathrm{kg} /$ fed. $)$

/ Irrigation water requirement $\left(\mathrm{m}^{3}\right.$ / fed.) $\}$

At harvest time, ten plants were chosen randomly from each sub-plot to estimate the following characters:

I. Plant height $(\mathrm{cm})$.

2. Leaves (no / plant).

3 . Ear length $(\mathrm{cm})$.

4. Rows (no / ear).

5. Grains no / ear

6. Grains index

7. Grains yield $\left(\mathrm{gm} / \mathrm{m}^{2}\right)$.

8. Grains yield (ton / fed).

Statistical analysis:

Mean values were compared for each other using the least significant differences (LSD).

\section{Results and Discussion}

Maize yield and yield components.

The effects of different irrigation systems, pulse system and silicon application on growth characteristics (plant height, leaves no / plant, Ear length $/ \mathrm{cm}$, Ear diameter $/ \mathrm{cm}$, Grains weight/ Ear, Grains index (weight as g/ 100 grains), Grains yield ton / fed) at 100 days of sowing during the two growth seasons were presented in Tables $2 \mathrm{a}$ to $2 \mathrm{c}$.

The obtained results which are represented in Tables $2 \mathrm{a}$ to $2 \mathrm{c}$ revealed that the experimental treatments has significant by affected growth characteristics. The results indicated that the (plant height, Leaves no / plant, Ear length $/ \mathrm{cm}$, Ear diameter $/ \mathrm{cm}$, Grains weight/ Ear, Grains index (weight as g/ 100 grains), Grains yield ton / fed) were significantly affected by using different irrigation systems, pulse system and silicon application in both seasons.

a- The Effect of irrigation systems on plant characteristics.

The ear length or grain index (weight as g/ 100 grains) was not changed significantly by irrigation system treatments (Tables 2a and $2 b)$. On the other hand, the plant height for combination irrigation system was higher than the subsurface and surface drip irrigation (Table 2a). The number of leaves per plant was significantly changed where as the combination irrigation system increases the number of leaves per plant (Table 2a). This resulted in higher grain yield $\left(\mathrm{gm} / \mathrm{m}^{2}\right)$. Also, the results indicated that grain yield (ton/fed) was increased for 
combined irrigation system by $33 \%$ and $60 \%$ more than that of the subsurface drip irrigation in both seasons, respectively (Table $2 \mathrm{c}$ ).

b- The Effect of pulse technique on plant characteristics.

The number of leaves per plant, ear length, number of rows per ear and grain index (weight as g/ 100 grains) was not changed significantly by pulse technique treatments (Tables $2 \mathrm{a}$ and $2 \mathrm{~b}$ ). On the other hand, the plant height for pulse technique treatment was higher than the treatments without pulse technique (Table 2a). The number of grain per ear was significantly changed where the pulse technique increased the number of grain per ear (Table $2 b$ ). This resulted in higher grain yield $\left(\mathrm{gm} / \mathrm{m}^{2}\right)$. Also, the results indicated that grain yield (ton / fed) was increased due to pulse technique treatments by $46 \%$ and $35.7 \%$ in both seasons respectively more than that was in without pulse technique treatments (Table 2c).

c- The Effect of silicon application on plant characteristics.

The plant height, ear length, number of rows per ear and number of grain per ear were not changed significantly by silicon treatments (Tables 2a and 2b). On the other hand, the number of leaves per plant was significantly changed where the silicon application increases the number of leaves per plant (Table 2a). This resulted in higher grain yield $\left(\mathrm{gm} / \mathrm{m}^{2}\right)$. Also, the results indicated that grains yield (ton/fed) was increased for silicon application treatments by $25 \%$ and $23 \%$ in both seasons, respectively more than that without silicon application treatments (Table 2c). 
Table 2a. Effect of irrigation systems, pulse irrigation technique and silicon application on some growth parameters and yield of maize plant.

\begin{tabular}{|c|c|c|c|c|c|c|c|c|c|c|}
\hline \multirow{2}{*}{\multicolumn{2}{|c|}{$\begin{array}{l}\text { Characters } \\
\text { Treatment }\end{array}$}} & \multicolumn{3}{|c|}{ plant height (m) } & \multicolumn{3}{|c|}{ No. leaves / plant } & \multicolumn{3}{|c|}{ Ear length(cm) } \\
\hline & & 2015 & 2016 & mean & 2015 & 2016 & mean & 2015 & 2016 & mean \\
\hline \multirow{4}{*}{$\begin{array}{l}\text { Irrigation } \\
\text { systems }\end{array}$} & $\mathbf{I}_{1 \text { (Sub surface) }}$ & 0.9 & 1.5 & 1.2 & 10.45 & 13.8 & 12.1 & 15.9 & 15.8 & 15.9 \\
\hline & & 1.2 & 1.6 & 1.4 & 10.9 & 14.3 & 12.6 & 17.6 & 16.5 & 17.1 \\
\hline & & 1.8 & 1.7 & 1.7 & 11.7 & 15.3 & 13.5 & 17.8 & 16.6 & 17.2 \\
\hline & L.S.D & 0.2 & 0.1 & - & 0.56 & 0.9 & - & N.S. & N.S. & - \\
\hline \multirow{3}{*}{$\begin{array}{l}\text { Pulse } \\
\text { once time }\end{array}$} & without & 1.1 & 1.7 & 1.4 & 11.2 & 14.3 & 12.8 & 16.2 & 15.9 & 16.1 \\
\hline & with & 1.5 & 1.6 & 1.6 & 10.9 & 14.7 & 12.8 & 18.0 & 16.7 & 17.4 \\
\hline & L.S.D & 0.2 & N.S. & - & N.S. & N.S. & - & N.S. & N.S. & - \\
\hline \multirow{3}{*}{$\begin{array}{l}\text { Si } \\
400(\mathrm{mg})\end{array}$} & & 1.3 & 1.6 & 1.5 & 10.6 & 14.0 & 12.3 & 17.0 & 15.7 & 16.4 \\
\hline & with & 1.3 & 1.7 & 1.5 & 11.4 & 14.9 & 13.2 & 17.2 & 16.9 & 17.1 \\
\hline & L.S.D 0.05 & N.S. & N.S. & - & 0.64 & 0.9 & - & N.S. & N.S. & - \\
\hline
\end{tabular}

NS No significant differences at 0.05 level

Table 2b. Effect of irrigation systems, pulse irrigation technique and silicon application on some growth parameters and yield of maize plant.

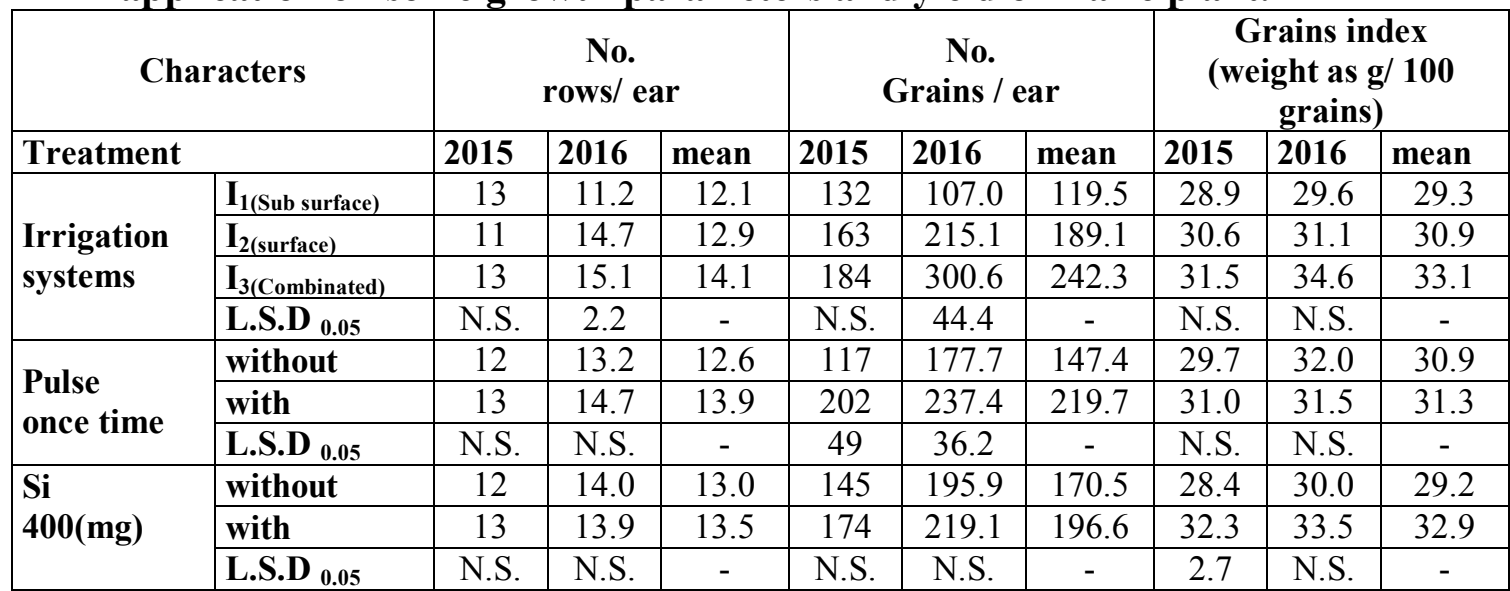

NS No significant differences at 0.05 level

Table (2c): Effect of irrigation systems, pulse irrigation technique and silicon application on some growth parameters and yield of maize plant.

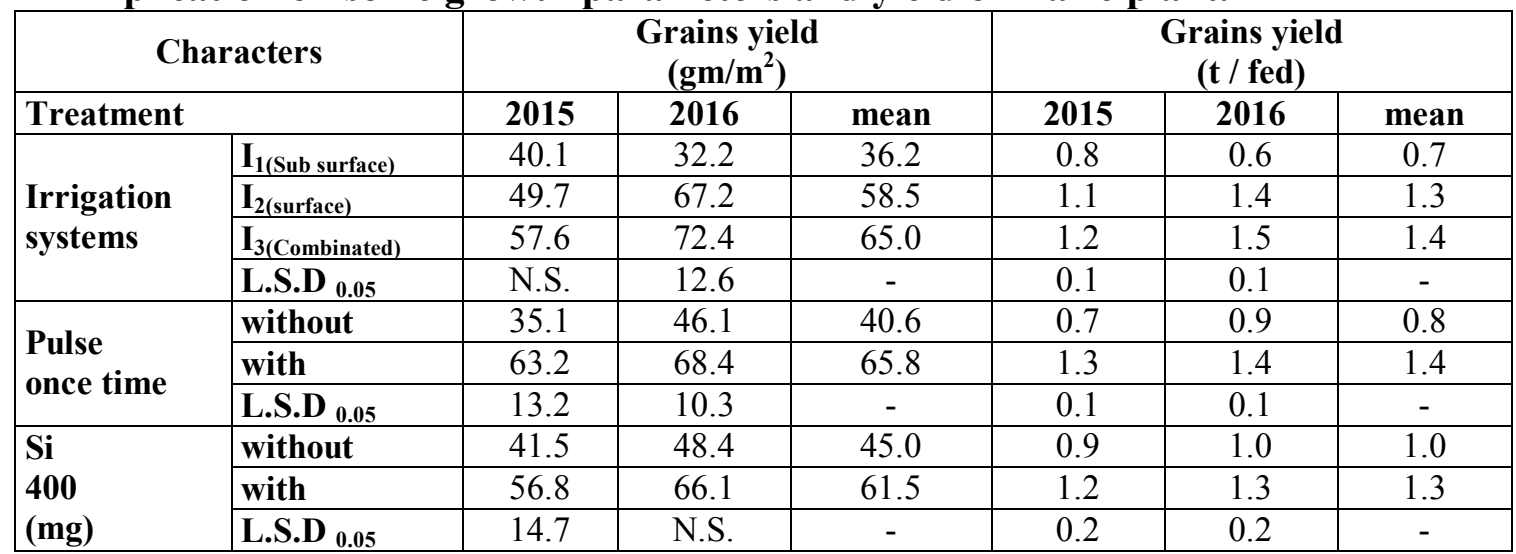

NS No significant differences at 0.05 level 
Table 3. Effect of irrigation systems, pulse irrigation technique and silicon application on Water use efficiency (WUE) and Irrigation water use efficiency (IWUE).

\begin{tabular}{|c|c|c|c|c|c|c|c|}
\hline \multirow{2}{*}{\multicolumn{2}{|c|}{ Characters }} & \multicolumn{3}{|c|}{$\begin{array}{l}\text { Water use efficiency } \\
\qquad\left(\mathrm{Kg} / \mathbf{m}^{3}\right)\end{array}$} & \multicolumn{3}{|c|}{$\begin{array}{c}\text { Irrigation water use } \\
\text { efficiency } \\
\left(\mathrm{Kg} / \mathbf{m}^{\mathbf{3}}\right)\end{array}$} \\
\hline & & 2015 & 2016 & mean & 2015 & 2016 & mean \\
\hline \multirow{4}{*}{$\begin{array}{l}\text { Irrigation } \\
\text { systems }\end{array}$} & $\mathbf{I}_{1 \text { (Sub surface) }}$ & 0.36 & 0.29 & 0.33 & 0.24 & 0.20 & 0.22 \\
\hline & $\mathbf{I}_{2 \text { (surface) }}$ & 0.42 & 0.55 & 0.49 & 0.30 & 0.41 & 0.36 \\
\hline & \begin{tabular}{|l|}
$I_{3}$ (Combinated) \\
\end{tabular} & 0.44 & 0.60 & 0.52 & 0.31 & 0.48 & 0.40 \\
\hline & L.S.D 0.05 & 0.02 & 0.01 & - & 0.02 & 0.02 & - \\
\hline \multirow{3}{*}{$\begin{array}{l}\text { Pulse } \\
\text { once time }\end{array}$} & without & 0.29 & 0.37 & 0.33 & 0.20 & 0.29 & 0.25 \\
\hline & with & 0.53 & 0.59 & 0.56 & 0.36 & 0.44 & 0.40 \\
\hline & L.S.D ${ }_{0.05}$ & 0.01 & 0.01 & - & 0.02 & 0.01 & - \\
\hline \multirow{3}{*}{$\begin{array}{l}\text { Si } \\
400 \\
(\mathrm{mg}) \\
\end{array}$} & without & 0.35 & 0.40 & 0.38 & 0.24 & 0.29 & 0.27 \\
\hline & with & 0.47 & 0.57 & 0.52 & 0.33 & 0.44 & 0.39 \\
\hline & L.S.D ${ }_{0.05}$ & 0.08 & 0.11 & - & 0.06 & 0.10 & - \\
\hline
\end{tabular}

NS No significant differences at 0.05 level.

a- The Effect of irrigation systems on Water use efficiency (WUE) and irrigation Water use efficiency:

Table (3) presents the effects of irrigation systems treatments on (WUE and IWUE) in both seasons. The $\mathrm{I}_{3}$ (combinated system) significantly increased (WUE and IWUE) over all other systems in both the years. Similarly, $\mathrm{I}_{2}$ (drip system) treatment were also superior in (WUE and IWUE) $\mathrm{I}_{1}$ (control) in both the seasons. Minimum (WUE and IWUE) were observed in $\mathrm{I}_{1}$ (control).

b- The Effect of pulse technique on water use efficiency (WUE) and irrigation water use efficiency:

The Table (3) showed the relation between pulse irrigation technique, and WUE and IWUE. From the above data, (WUE and IWUE), were increased due to using the pulse irrigation. This may be due to de- creasing of water penetration downward by increasing of initial moisture content which, was increased by increasing number of pulses. Hence, pulse technique increased from water movement in horizontal direction than vertical direction this action increased the wetted soil volume inside root zone and this mean increasing in (WUE). These results are agreement with Scott, 2000 and Oron, 1981.

c- The Effect of silicon application on water use efficiency (WUE) and irrigation water use efficiency:

Data of Table 3 reveal that silicon treatments had significant effect on WUE and IWUE. Result might be attributed to the positive effect of silicon that improve the (WUE and IWUE) that might be due decrease in unnecessary transpiration. These results are agreement with those obtained by Hellal et al., 2012 and $\mathrm{Pu}-$ tra et al., 2012. 


\section{References}

Agarie, S., H. Uchida, W. Agata, F Kubota and P.B Kaufman. 1998. Effects of silicon on transpiration and leaf conductance in rice plants (Oryza sativa L.) plant prod. Sci., 1:89-95.

Ayars, J. E., C. J. Phene, R. B. Hutmacher, K. R. Davis, R. A. Shoneman,S. S. Vail and R. M. Mead. 1999. Subsurface drip irrigation of row crops: A review of 15 years of research at the Water Manag. Lab., Agric. Water Manag., 42 (1):1-27, USA.

El-Atawy G. S., Eid S.M. 2010. Influence of irrigation water amounts and nitrogen rate on maize productivity and some water relation in Wadi Elnatroon region, Egypt . J. Soil Sci. and Agric. Engineering Univ., 1(8): 75-87.

El-Shamly, A. M. 2014. Water Requirement of Wheat and Sesame Crops Grown in Toshka Soil Under Sprinkler Irrigation System. M. Sc. Thesis, Fac. Agric., Assiut Univ., Egypt.

EL-Sheikh, M.A. 1994. Response of two maize varieties to plant densities and irrigation treatments. J. Agric. Sci. Mansoura Univ., 19(2): 413-422.

Epstein, E. 2009. Silicon: its manifold roles in plants. Ann. Appl. Biol., 155: $155-160$.

Gong.H., X.Zhu, K.Chen, S.Wang and C.Zhang. 2005. Silicon alleviates oxidative damage of wheat plants in pots under drought. Plant Sci., 169: 313-321.

Hefni, E.H.M., A.A. El-Hosary, M.I.M. Salwau and A. El- Shabbagh. 1993. Effect of soil moisture stress and zinc on some maize varieties. Ann. Agric. Sci. Moshtohor, 31(4): 1813-1828.

Hellal, F.A., R.M. Zeweny and A.A. Yassen. 2012. Evaluation of ni- trogen and silicon application for enhancing yield production and nutrient uptake by wheat in clay soil. J. Appl. Sci. Res., 8: 686692.

Ibrahim, M.E., H.M.M. El-Naggar and A.A. El-Hosary. 1992. Effect of irrigation intervals and plant densities on some varieties of corn. Menofiya J. Agric. Res., 17(3): 1083-1098.

Israelsen, O.W. and V.E. Hansen 1962. Flow of water into and through soils.Irrigation principles and practices. $3^{\text {rd }}$ Edition, John Wiley and Sons, Inc., New York, U.S.A.

Klute, A.E. 1986. Methods of Soil Analysis. Part-1.physical and Mineralogical Methods. ( $2^{\text {nd }}$ edition). Amer. Soc. Agro. Madison, Wisconsin, U.S.A.

Kojic, D., S. Pajevic, A. JovanovicGalovic, J. Purac, E. Pamer, S. Skondric, S. Milovac, Z. Popovic and G. Grubor-Lajsic. 2012. Efficacy of natural aluminosillicates in moderating drought effects on the morphological and physiological parameters of maize plants (Zea mays.L.).J. Soil Sci. and Plant Nutr., 12: 113-123.32.

Liang, Y.C., S. Qirong and S. Zhenguo. 1999. Effect of silicon on enzyme activity and sodium, potassium and calcium concentration in barley under salt stress. J. Plant Soil, 209: 217-224.

Mahrous, N.M. 1991. Performance of some corn cultivars under some water stress treatments. Bull. Fac. of Agric. Cairo Univ., 42 (4): 1117-1132.

Mali, M. and N.C. Aery. 2008. Influence of silicon on growth relative water contents and uptake of silicon, calcium and potassium in wheat grown in nutrient solution. J. Plant Nutr., 31: 1867-1876. 
Matichenkov, V.V. and E.A. Bocharnikova. 2001. The relationship between silicon and soil physical and chemical properties. In: L.E. Datno. G.H. Synder, H. Korndorfer, (eds). Silicon in agriculture. Amsterdam: Elsevier, pp. 209-219.

MWRI. 2014. Water scarcity in Egypt: The Urgent Need for Regional Cooperation among the Nile Basin Countries. ed: Ministry of Water Resources and Irrigation, 2014.

Nabila, M. Zaki, Amal, G. Ahmed, M.S. Hassanein, Manal, F. Mohamed and M.M. Tawfik. 2014. Yield and yield components of two maize hybrids as influenced by water deficit and amino cat fertilizer. Middle East J. of Applied Sci., 4 (3):648-654.

Oron, G. 1981. Simulation of water flow in the soil under sub-surface trickle irrigation with water uptake by roots. Agric. Water Manage. 3: 179-193.

Page, A.1. 1982. Method of soil analysis.Part-2: Chemical and microbiological properties, (2 nd Ed.), American Society of Agronomy, Madison, Wisconsin,

Pei, ZIF.S.D.F. Ming, D. Liu, G.L. Wan, X.X. Geng, H.J. Gong and W.J. Zhou. 2010. Silicon improves the tolerance to water-deficit Stress induced by polyethylene glycol in wheat seedlings. J. Plant Growth Regul., 29: 106-115.

Putra, E.T.S., W. Zakaria, N.A.P. Abdullah and G.B. Saleh. 2012.
Stomatal morphology, conductance and transpiration of Musa sp. cv. Rastali in relation to Magnesium, Boron and Silicon availability. Am. J. Plant Physiol., 7: 84-96.

Scott, C. 2000. Pulse Irrigation. Water Savings Indiana Flower Growers Association. Vol. 14, No.1. Cooperating with The Department of Horticulture and Landscape Architecture Cooperative Extension Service Purdue University West Lafayette, pp: 120.

Segal, E., A. Ben-Gal., and U. shani. 2000. Water availability and yield response to high-frequency microirrigation in sunflowers, Proceedings of the $\mathrm{Six}^{\text {th }}$ international Micro-irrigation Congress on "Micro irrigation Technology for Developing Agriculture" Conference Papers, 22-27 October South Africa.

Simpson, G.M. 1981. Water stress on plants .CBS Educational and Professional publishing, New York, USA.

Smith, J. and P. J. Watts. 1986. Analysis and design of gated irrigation pipelines. Agric. Water Manage. 12, 99 - 115.

Viets, F. G. Jr. 1965. Fertilizers and the efficient use of water. Advanced in Agronomy, 14. 228-261.

Walker, W. R. 1989. Guidelines for designing and evaluating surface irrigation systems. FAO Irrig. and Drain. Paper No. 45: 137 pp., Italy. 
تأثير إستخدام نظم الري المختلفة وتقنية الري النبضي والسليكون على النمو الخضري

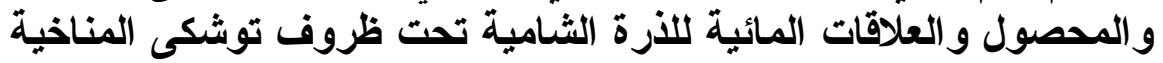

أحمد سليمان دهب أباظة'، حسين محمد علي راغب` ، محمد كمال رشدي ' وعمر حامد أحمد'

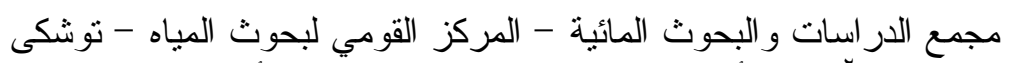

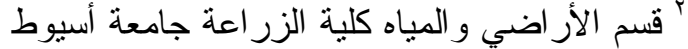

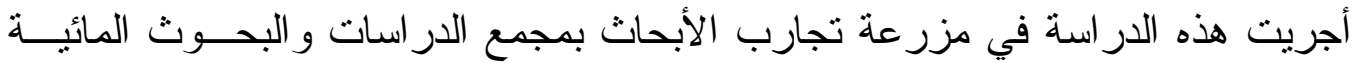

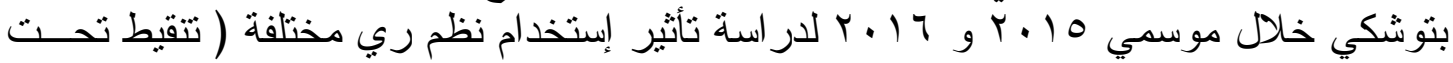

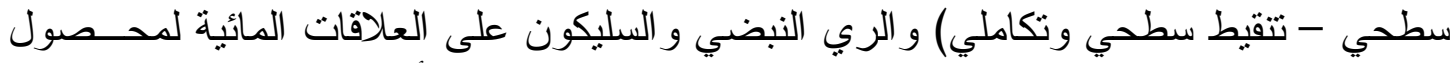

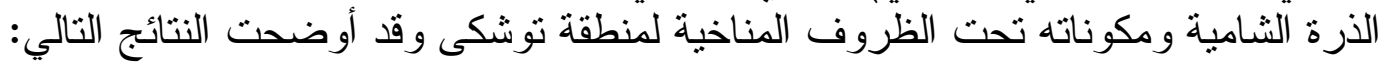

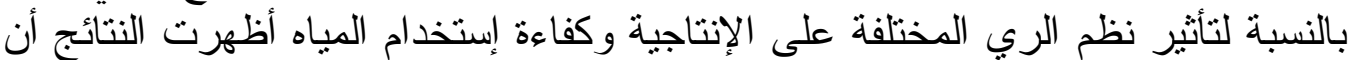

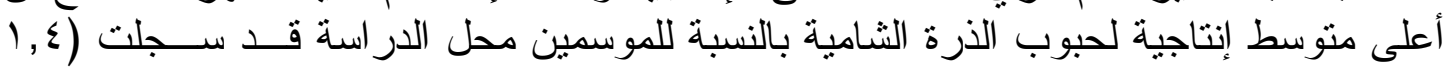

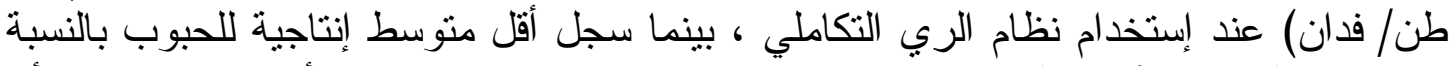

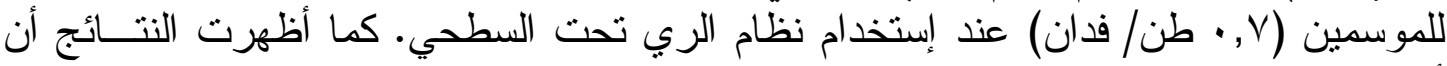

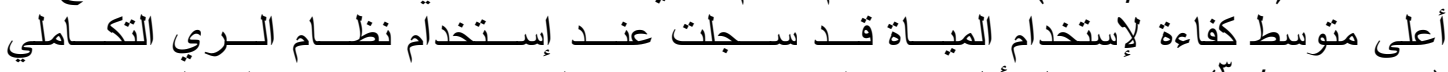

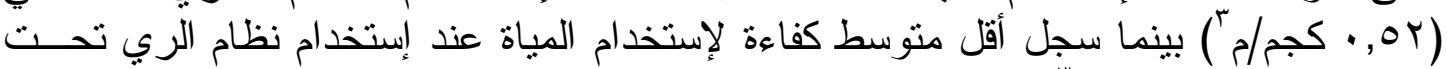

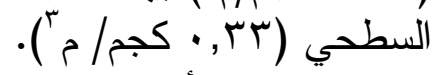

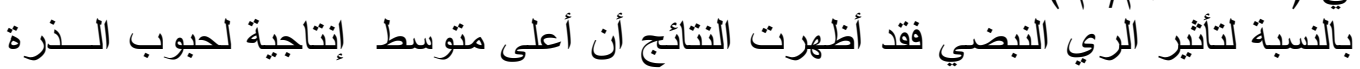

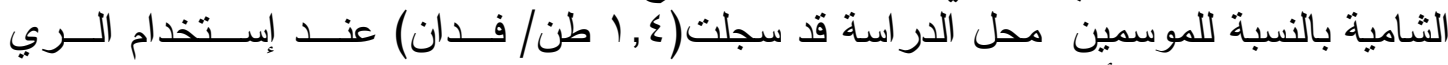

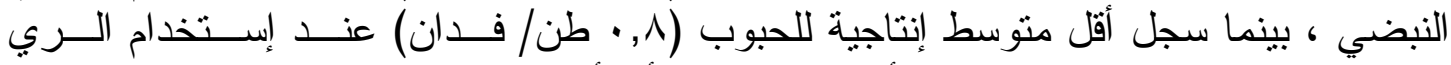

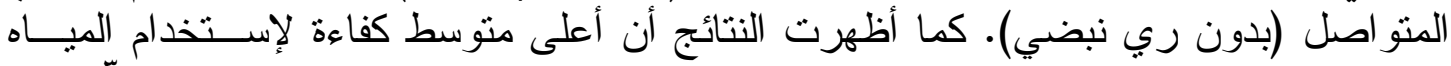

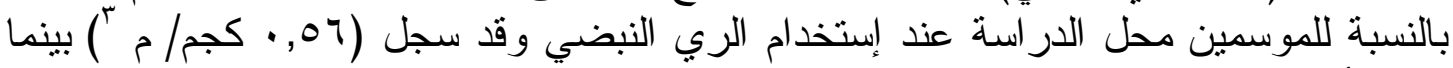

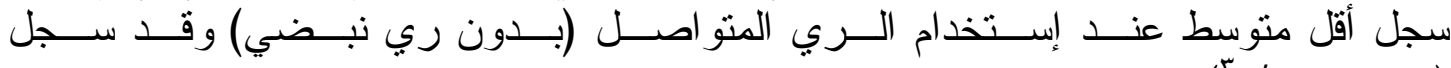

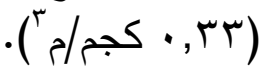

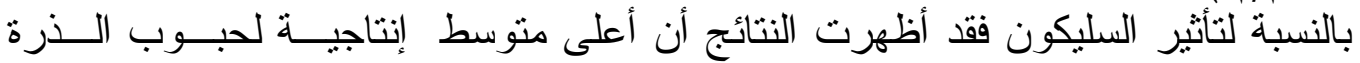

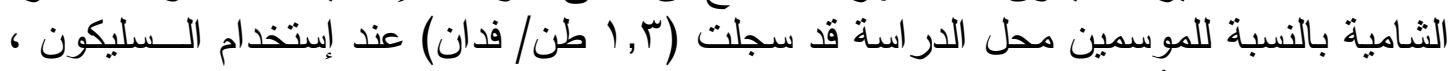

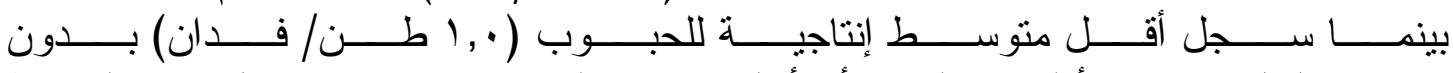

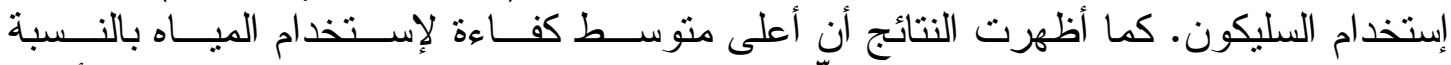

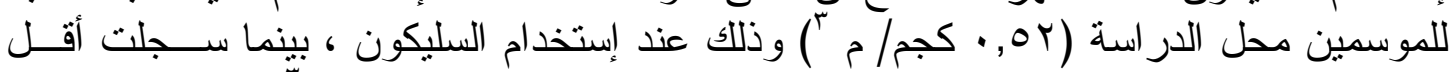

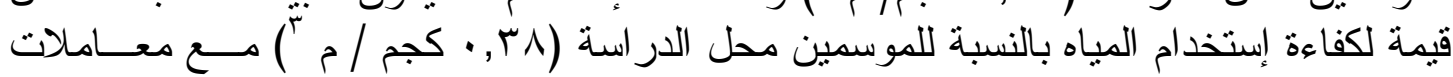
بلدون سليكون.

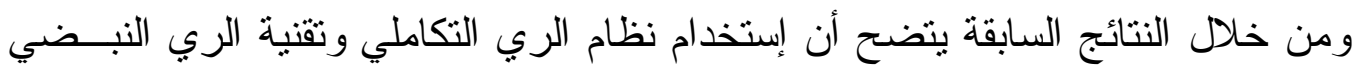

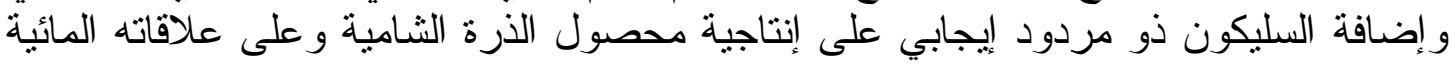
تحت ظروف توشكى المناخية. الكلمات الدالة: تقنية الري النبضي ، إستخدام السليكون ، الذرة الثامية 